\title{
Rational Color Tuning and Luminescent Properties of Functionalized Boron-Containing 2-Pyridyl Pyrrolide Complexes**
}

\author{
By Hsing-Yi Chen, Yun Chi,* Chao-Shiuan Liu, Jen-Kan Yu, Yi-Ming Cheng, Kung-Shih Chen, \\ Pi-Tai Chou,* Shie-Ming Peng, Gene-Hsiang Lee, Arthur J. Carty, Shi-Jay Yeh, and Chin-Ti Chen*
}

Three systematically functionalized pyrrolide ligands were prepared via the coupling of methyl vinyl ketone and the respective carbaldehyde reagents, followed by treatment of the pre-formed dicarbonyl compounds with $\left(\mathrm{NH}_{4}\right)_{2} \mathrm{CO}_{3}$ in order to generate the required pyrrole fragment. These ligands readily reacted with the boron reagent $\mathrm{BPh}_{3}$ to afford the complexes $\left[(\mathrm{pyro}) \mathrm{BPh}_{2}\right]$ (2a), [(noro) $\left.\mathrm{BPh}_{2}\right]$ (2b), and [(xaro) $\left.\mathrm{BPh}_{2}\right](\mathbf{2 c})$, where (pyro) $\mathrm{H}$, (noro) $\mathrm{H}$, and (xaro) $\mathrm{H}$ represents the 2-pyridyl, 2-quinolinyl, and 2-quinoxalinyl pyrrole groups, respectively. Complexes $2 \mathbf{a}-\mathbf{2 c}$ give stable solutions in air, and show strong photoluminescence with emission peak maxima located at $490 \mathrm{~nm}, 510 \mathrm{~nm}$, and $575 \mathrm{~nm}$, respectively. Calculations based upon time-dependent density function theory (TDDFT) show that the $S_{1}$ state in these complexes is attributed to an allowed ( $\pi$-symmetry) $\rightarrow \pi^{*}$ ( $\pi$-symmetry) transition located at the chelating pyrrolide moieties. Electroluminescence (EL) devices based on $\mathbf{2 c}$ were fabricated. The EL emission from $\mathbf{2 c}$ as the host-emitter, with the emission peak maximum shifted to $580 \mathrm{~nm}$, was observed when BCP was used as the hole blocking material. This device produces saturated red-orange light-emission at an onset voltage of $8 \mathrm{~V}$ and a maximum brightness of $5000 \mathrm{~cd} \mathrm{~m}^{-2}$ at a driving voltage of $15 \mathrm{~V}$; the external quantum yield is estimated to be $0.5 \%$.

\section{Introduction}

Boron complexes with conjugated light-emitting $\pi$-systems have recently received considerable attention due to their potential use in organic light-emitting devices (OLEDs) ${ }^{[1]}$ as well as fluorescent probes for proton or heavy metal ion detection. ${ }^{[2]}$ The best known family of molecules characterized to date are a class of well-established boron dipyrromethene (BDP) dyes prepared via a direct condensation of the pyrrole, carbaldehyde and boron reagents. ${ }^{[3]}$ These dyes show high molar extinction coefficients and strong fluorescence over a broad range of wavelengths. As a result, it would be of great interest to chemically modify these boron complexes so that their physical properties can be fine-tuned for specialized applications. Other boron containing complexes that exhibit strong photolu-

[*] Prof. Y. Chi, H.-Y. Chen, Prof. C.-S. Liu

Department of Chemistry, National Tsing Hua University

Hsinchu 300 Taiwan (R.O.C.)

E-mail: ychi@mx.nthu.edu.tw

Prof. P.-T. Chou, J.-K. Yu, Y.-M. Cheng, K.-S. Chen,Prof. S.-M. Peng,

G.-H. Lee

Department of Chemistry and Instrumentation Center

National Taiwan University

Taipei 106 Taiwan (R.O.C.)

E-mail: ehop@ntu.edu.tw

Prof. A. J. Carty

Steacie Institute for Molecular Sciences, National Research Council

Ontario K1A OR6 (Canada)

Dr. C.-T. Chen, S.-J. Yeh

Institute of Chemistry, Academia Sinica

Taipei 11529 Taiwan (R.O.C.)

E-mail: cchen@chem.sinica.edu.tw

[**] We thank the National Science Council of Taiwan, for the financial supports (NSC 91-2119-M-002-016) and (NSC 91-211-M-007-006). P.T.C. also thanks $\mathrm{NCHC}$ for the use of their computing facilities. minescence in the blue, green, and red spectral regions have also been prepared, for potential application in OLEDs. ${ }^{[4]}$ In this article, we report the synthesis, characterization, and theoretical investigation of a new series of boron complexes bearing substituted 2-(2-pyridyl) pyrrolide ligands. We anticipated that these ligands would serve as excellent bidentate chelates upon treatment with a boron reagent such as $\mathrm{BPh}_{3}$ under mild conditions, affording a planar, rigid, and highly conjugated $\pi$-system perfectly tailored in order to enhance the luminescent properties. In addition, we introduced a range of functional groups on the aromatic $\pi$-system so that the photophysical properties could be further modified. We expect that such a design strategy might conceptually lead to the development of new dyes with high fluorescent quantum yields at the assumed emission wavelengths, ${ }^{[5]}$ particularly suited to the current search for practical OLEDs.

\section{Results and Discussion}

\subsection{Preparation and Characterization}

We have designed and synthesized a series of functionalized pyrrolide ligands in order to tailor their emission properties. Our strategy consists of using polyaromatic substituents such as pyridyl, quinolinyl, and quinoxalinyl groups. These substituted pyrroles were prepared by a two-step process, which included the synthesis of a 1,4-dicarbonyl compound via the Stetter method from methyl vinyl ketone and the respective carbaldehyde reagents, followed by treatment of the preformed dicarbonyl compound with ammonium carbonate to complete the formation of the pyrrole ring. ${ }^{[6]}$ We suspected that the pyrrole $\mathrm{N}-\mathrm{H}$ bond of these ligands would be highly acidic, and with assistance from the adjacent nitrogen donor, 
would lead to facile coordination to a wide variety of main group metal atoms, affording the designed bidentate chelate complexes. ${ }^{[7]}$ As expected, treatment of these pyrrolide ligands 1a-1c with the boron reagent $\mathrm{BPh}_{3}$ in tetrahydrofuran (THF) solution at room temperature gave the target $\mathrm{BPh}_{2}$ complexes 2a-2c, in yields of $\sim 63 \%$. The key reactants and intermediates leading to the synthesis of the 5-methyl-2-(2-pyridyl) pyrrolide boron complex 2a, together with the proposed structures of the other complexes $\mathbf{2 b}$ and $\mathbf{2 c}$ are outlined in Scheme 1. All three complexes are highly soluble in chlorinated solvents such as $\mathrm{CH}_{2} \mathrm{Cl}_{2}$ and show negligible decomposition upon exposing the solution to air and moisture, even over an extended period of time. As a result, purification was conducted using a combination of vacuum sublimation and recrystallization.

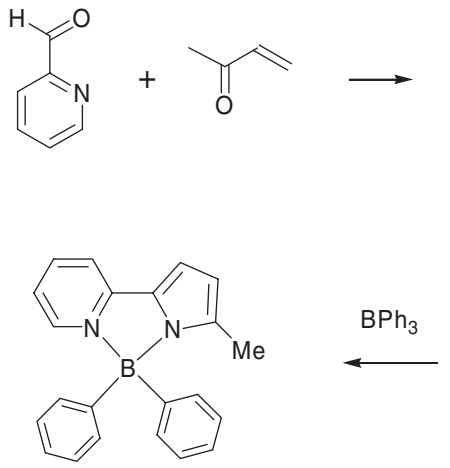

(2a)

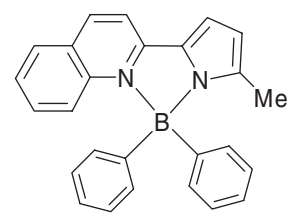

(2b)<smiles>CC(=O)CCC(=O)c1ccccn1</smiles>

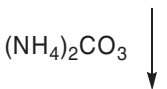

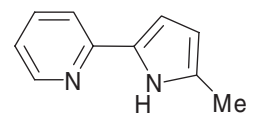

(1a)

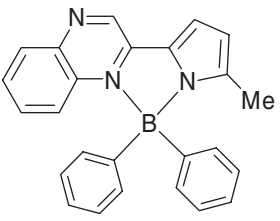

(2c)
Scheme 1 The key reactants and intermediates leading to the synthesis of the 5-methyl-2-(2-pyridyl) pyrrolide boron complex $2 \mathbf{a}$, together with the proposed structures of the additional complexes $\mathbf{2} \mathbf{b}$ and $\mathbf{2} c$.

A single-crystal X-ray analysis on $\mathbf{2 c}$ was conducted to confirm the structural identity of the complex. As shown in Figure 1, this molecule consists of a tetrahedrally coordinated boron atom with two carbon and two nitrogen ligands. The bond angles subtended at the boron atom by these pairs of donors are $\mathrm{C}(14)-\mathrm{B}(1)-\mathrm{C}(20)=119.3(2)^{\circ}$ and $\mathrm{N}(1)-\mathrm{B}(1)-\mathrm{N}(2)=$ $94.5(1)^{\circ}$. The acute value of the latter is almost certainly a result of the formation of the five-membered chelate ring. The bond distances involving the chelating 2-quinoxalinyl pyrrolide ligand bond are: $\mathrm{B}(1)-\mathrm{N}(1)=1.568(3) \AA$ and $\mathrm{B}(1)-\mathrm{N}(2)=$ 1.632(2) $\AA$. Thus, the more covalent $N$ (pyrrolide)-B distance is found to be distinctively shorter than that of the second $\mathrm{N} \rightarrow \mathrm{B}$ dative bond. This observation is consistent with other structural data reported in related $\mathrm{BPh}_{2}$ complexes with chelating (2-pyridyl)-7-azaindole and 2-( 2 -pyridyl) indole ligands. ${ }^{[4]}$ Moreover, the phenyl rings are orthogonal to the quinoxalinyl pyrrolide

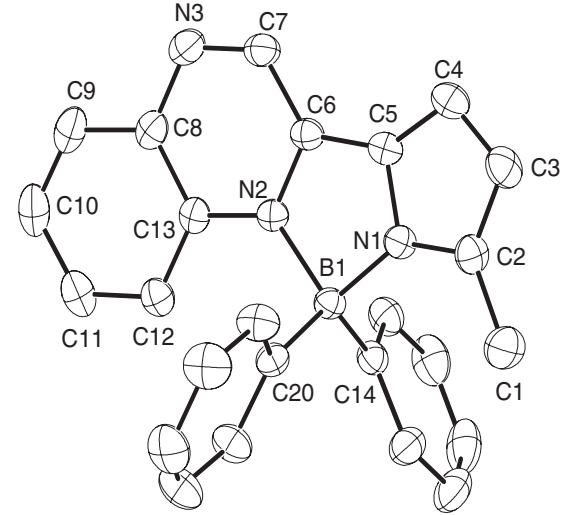

Figure 1. ORTEP diagram of complex $2 c$ with thermal ellipsoids shown at $30 \%$ probability.

ligand, despite the fact that the methyl substituent on the pyrrolide fragment points at these phenyl groups. Similar crystal structures are likely for $\mathbf{2 a}$ and $\mathbf{2 b}$. Their overall molecular structure resembles that of the 9,9-disubstituted fluorene compounds, ${ }^{[8]}$ which have been widely used as promising bluephosphors in OLED applications.

\subsection{Photophysical Properties}

As shown in Figure 2, the UV-visible absorption and emission spectra of the three complexes exhibited similar spectral features with an intense peak maximized at 395,442 , and $492 \mathrm{~nm}$ for $\mathbf{2 a}, \mathbf{2 b}$, and $\mathbf{2 c}$, respectively. Moreover, the absorption peaks for these complexes have a large molar extinction

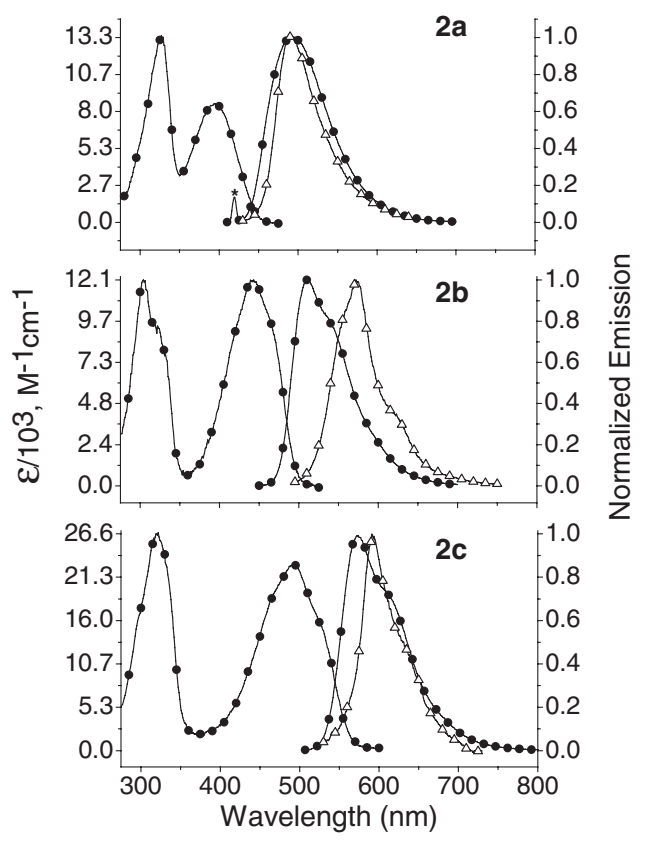

Figure 2. The UV-visible absorption (0) and emission spectra (solution -; solid $\triangle$ ) of complexes $\mathbf{2 a}, \mathbf{2 b}$, and $\mathbf{2 c}$ dissolved in $\mathrm{CH}_{2} \mathrm{Cl}_{2}$ at room temperature. * denotes Raleigh scattering. 
coefficient of the order of $\sim 10^{4} \mathrm{M}^{-1} \mathrm{~cm}^{-1}$, which was insensitive to solvent polarity. Thus, the characteristic absorption band can reasonably be assigned to a ligand-centered $S_{0} \rightarrow S_{1}\left(\pi-\pi^{*}\right)$ transition. This viewpoint was further confirmed via an extensive ab-initio theoretical approach as described in the following section. The emission spectra for $\mathbf{2 a - c}$ revealed a vibronic-like progression. Proof that the entire emission band likely originates from a common ground-state species is shown by observation of the same fluorescence excitation spectra throughout the monitored wavelengths of $500-700 \mathrm{~nm}$. The excitation spectra, within experimental error, are also effectively identical to the absorption spectrum, indicating that the entire emission results from a common Franck-Condon excited state. The population decay time for compounds $\mathbf{2 a}, \mathbf{2 b}$, and $\mathbf{2 c}$, was measured to be $11.8,8.85$, and $1.9 \mathrm{~ns}$, respectively, and found to be oxygen-concentration $(0-1 \mathrm{~atm})$ independent in various solvents studied (Table 1). This, in combination with the overlapping of

Table 1. Photophysical properties of complexes $\mathbf{2 a - 2 c}$ and deprotonated ligand chromophores $1 \mathbf{a}^{-}-1 \mathbf{c}^{-}$. Note $1 \mathbf{a}^{-}-1 \mathbf{c}^{-}$were prepared in basified eth anol at $25^{\circ} \mathrm{C} . \mathrm{CH}_{2} \mathrm{Cl}_{2}$ was used as a solvent for $\mathbf{2 a}-\mathbf{2} \mathbf{c}$ in solution phase.

\begin{tabular}{lllll}
\hline & $\begin{array}{l}\lambda_{\text {abs, }}, \mathrm{nm} \\
{\left[\varepsilon, \mathrm{M}^{-1} \mathrm{~cm}^{-1}\right]}\end{array}$ & $\begin{array}{l}\lambda_{\mathrm{em}}, \\
{[\mathrm{nm}]}\end{array}$ & $\Phi$ & $\begin{array}{l}\tau \\
{[\mathrm{ns}]}\end{array}$ \\
\hline $\mathbf{1 \mathbf { a } ^ { - }}$ & $370(\mathrm{~N} / \mathrm{A})$ & 505 & $6.0 \times 10^{-3}$ & $\mathrm{~N} / \mathrm{A}[\mathrm{a}]$ \\
$\mathbf{1 b}^{-}$ & $435(\mathrm{~N} / \mathrm{A})$ & 535 & $6.4 \times 10^{-5}$ & $\mathrm{~N} / \mathrm{A}[\mathrm{a}]$ \\
$\mathbf{1 c}^{-}$ & $485(\mathrm{~N} / \mathrm{A})$ & 608 & $3.6 \times 10^{-5}$ & $\mathrm{~N} / \mathrm{A}[\mathrm{a}]$ \\
$\mathbf{2 a}$ & $327(13470)$ & $490(490[\mathrm{~b}])$ & 0.52 & 11.81 \\
& $395(8580)$ & & & $7.8[\mathrm{~b}]$ \\
$\mathbf{2 b}$ & $304(12110)$ & $510(572[\mathrm{~b}])$ & 0.63 & 8.85 \\
& $324(\mathrm{sh})(9250)$ & 540 & & $4.96[\mathrm{~b}]$ \\
& $442(11990)$ & & & \\
& $465(\mathrm{sh})(9530)$ & & 0.14 & 1.90 \\
$\mathbf{2 c}$ & $322(26750)$ & $572(595[\mathrm{~b}])$ & & $1.56[\mathrm{~b}]$ \\
& $492(23460)$ & 610 & & \\
\hline
\end{tabular}

[a] Not available due to the system response limited lifetime. [b] Denotes the solid state property.

the $0-0$ onsets and the small amplitude of the Stokes shift $\left(<5000 \mathrm{~cm}^{-1}\right)$, (defined as the peak-to-peak frequency between absorption and emission) led us to conclude that the emissions originate from the prompt $\mathrm{S}_{1} \rightarrow \mathrm{S}_{0}\left(\pi-\pi^{*}\right)$ fluorescence.

Intriguingly, as shown in Figure 2, both absorption and emission underwent bathochromic shifts from $2 \mathbf{2 a}, \mathbf{2 b}$ to $\mathbf{2 c}$. Qualitatively, it is reasonable to anticipate that the lowest electronic excitation incorporates pyrrolide (highest occupied molecular orbital (HOMO)) and pyridine-containing (lowest unoccupied molecular orbital (LUMO)) moieties (vide infra). Accordingly, the systematic bathochromic shift can be rationalized by the more elongated $\pi$ conjugated system in the quinoline moiety (in $\mathbf{2 b}$ ) than pyridine (in 2a), so that the LUMO of $\mathbf{2 b}$ is stabilized, resulting in a smaller $\pi-\pi^{*}$ energy gap. Further lowering of the $\pi-\pi^{*}$ transition can thus be achieved by introducing an additional nitrogen atom on the quinoline, forming $\mathbf{2 c}$, in which the nitrogen atom serves as an electron-withdrawing group for the LUMO of the complex, rendering a further decrease of the $\pi-\pi^{*}$ energy gap. It is also worth noting that the emission quantum yields $\left(\Phi_{\mathrm{f}}\right)$ were greatly enhanced to $0.15-0.6$ in the complexes in comparison to that of $\Phi_{\mathrm{f}} \ll 0.01$ measured for the deprotonated ligands in basified $(\mathrm{KOH})$ ethanol (see Table 1). These results can be tentatively rationalized as due to the structural rigidity of the ligand in the as-prepared complexes due to the chelation. Thus, the rate of the nonradiative process induced by the skeletal motions was drastically suppressed in $\mathbf{2 a -}$ $\mathbf{2 c}$, whereas quenching via torsional motion might be expected for the corresponding free anionic ligands 1a-1c. Nevertheless, $\Phi_{\mathrm{f}}$ of $\mathbf{2} \mathbf{c}$ is lower than that of $\mathbf{2 a}$ and $\mathbf{2} \mathbf{b}$ by a factor of $\sim 4$, indicating the occurrence of a faster radiationless rate in $\mathbf{2 c}$, possibly due to the lower emission gap. This viewpoint is also supported by the shortest population lifetime of $1.9 \mathrm{~ns}$ for $\mathbf{2 c}$ among the three studied complexes.

\subsection{Theoretical Approaches}

Theoretical confirmation of the underlying basis for the photophysical properties of the boron complexes was provided by the ab-initio calculations. With our current computing capacity, converged complete active space-self consistent field (CASSCF) calculations with extended basis sets are not practical for dealing with the excited-state properties. Alternatively, the single configuration interaction (CIS) method, which has proven to be a relatively useful method to obtain approximate wavefunctions and molecular geometries of electronic excited states, can be applied. However, the CIS method usually overestimates the energy differences between the excited and ground states as well as the excited-state barriers. Conversely, although the time-dependent density functional theory (DFT) method currently cannot perform geometry optimization for the excited states, it has been shown to generate very reliable vertical excitation energies for low-lying excited states. ${ }^{\left[{ }^{[9]}\right.}$ Thus, an attempt to estimate the normal energy gap of absorption has been made on a vertical excitation in which the excitedstate geometry was taken from the ground-state optimized structure. This has been performed using the TD-B3LYP level at B3LYP geometry.

Figure 3 depicts the structures of the two lowest unoccupied and two highest occupied frontier molecular orbitals mainly involved in the transition of low-lying excited states using TD-B3LYP//B3LYP/6-31G(d $\left(\mathrm{d}^{\prime}, \mathrm{p}^{\prime}\right)$ method. The $\mathrm{S}_{1}$ state has a contribution from HOMO $\rightarrow$ LUMO, LUMO +1 . The results predict that the $\mathrm{S}_{1}$ state in the three complexes can be very well described using an allowed ( $\pi$-symmetry) $\rightarrow \pi^{*}$ ( $\pi$-symmetry) transition located at the 1a, 1b, and 1c ligand moieties of the corresponding complexes (see Table 2 and Fig. 3). With the use of the TD-B3 LYP method incorporating the B3 LYP/6$31 \mathrm{G}\left(\mathrm{d}^{\prime}, \mathrm{p}^{\prime}\right)$ optimized geometry, the vertical (i.e., Franck-Condon) excitation energy from the ground-state to the $S_{1}\left({ }^{1} \pi-\pi^{*}\right)$ state was calculated to be $25000 \mathrm{~cm}^{-1}(400 \mathrm{~nm}), 23000 \mathrm{~cm}^{-1}$ $(435 \mathrm{~nm})$, and $21500 \mathrm{~cm}^{-1}(465 \mathrm{~nm})$ for complexes $\mathbf{2 a}, \mathbf{2 b}$, and $\mathbf{2 c}$, respectively, which is in remarkable agreement with the corresponding experimental results of $395 \mathrm{~nm}$ for (2a), $442 \mathrm{~nm}$ for (2b), and $492 \mathrm{~nm}$ for (2c). In addition, the calculated oscillator strength, $f$, of 0.0724 for the case of $\mathbf{2 a}$ is in excellent agreement 


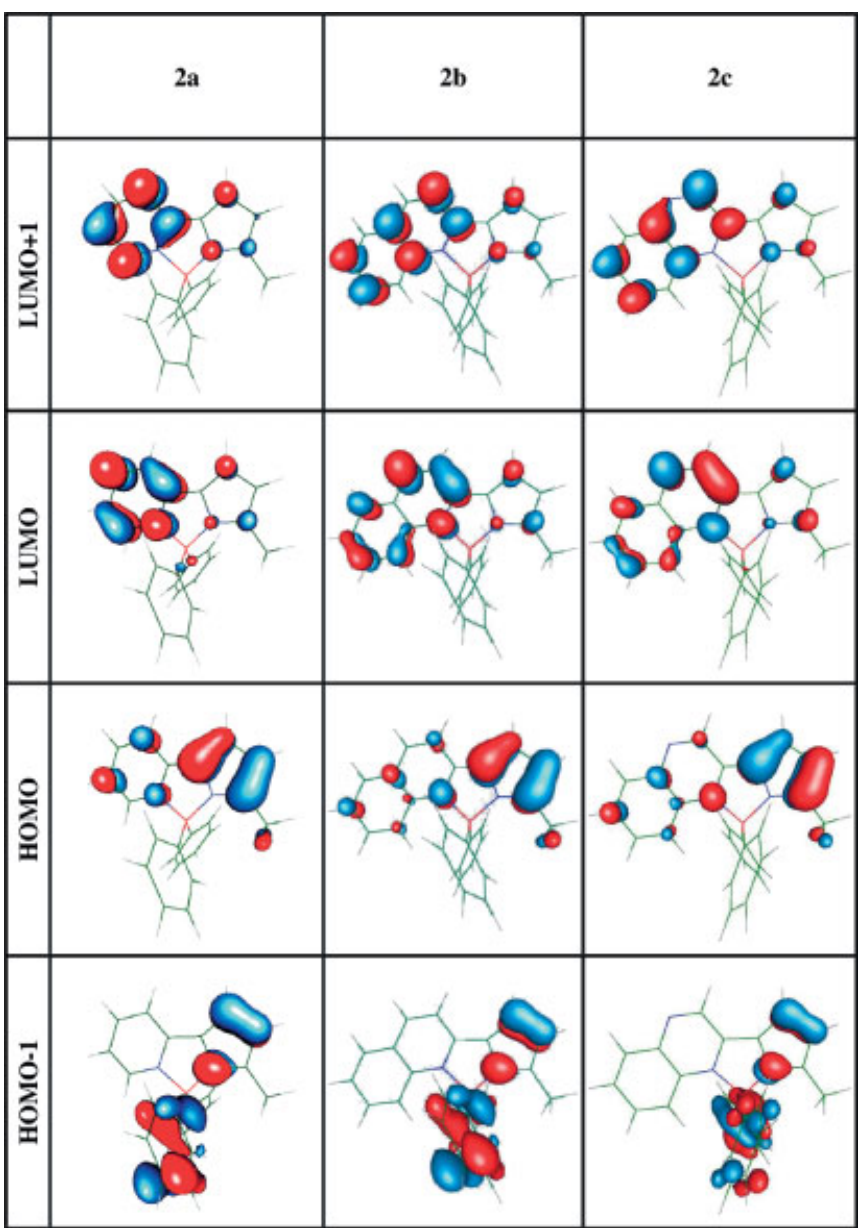

Figure 3. The calculated frontier orbitals for complexes $\mathbf{2 a}, \mathbf{2 b}$, and $\mathbf{2 c}$.

Table 2. The calculated electronic transitions of complexes $\mathbf{2 a}, \mathbf{2 b}$, and $\mathbf{2 c}$.

\begin{tabular}{|c|c|c|c|c|}
\hline & Transition & $\begin{array}{l}\text { Energy gap } \\
{[\mathrm{eV}]}\end{array}$ & $\begin{array}{l}\text { Molecular orbital } \\
\text { contribution }\end{array}$ & $\begin{array}{l}\text { Oscillator } \\
\text { strength }[\mathrm{f}]\end{array}$ \\
\hline \multirow[t]{2}{*}{$2 a$} & $\mathrm{~S}_{0} \rightarrow \mathrm{S}_{1}$ & $3.09[400 \mathrm{~nm}]$ & $\begin{array}{l}\text { HOMO } \rightarrow \text { LUMO } \\
\text { HOMO } \rightarrow \text { LUMO+1 }\end{array}$ & 0.0724 \\
\hline & $S_{0} \rightarrow S_{2}$ & $3.74[332 \mathrm{~nm}]$ & $\begin{array}{l}\text { HOMO- } 1 \rightarrow \text { LUMO } \\
\text { HOMO } \rightarrow \text { LUMO+1 }\end{array}$ & 0.029 \\
\hline \multirow[t]{2}{*}{$2 b$} & $\mathrm{~S}_{0} \rightarrow \mathrm{S}_{1}$ & $2.85[435 \mathrm{~nm}]$ & $\begin{array}{l}\text { HOMO } \rightarrow \text { LUMO } \\
\text { HOMO } \rightarrow \text { LUMO+1 }\end{array}$ & 0.1898 \\
\hline & $\mathrm{S}_{0} \rightarrow \mathrm{S}_{2}$ & $3.36[369 \mathrm{~nm}]$ & HOMO-1 $\rightarrow$ LUMO & 0.0083 \\
\hline \multirow[t]{2}{*}{$2 c$} & $\mathrm{~S}_{0} \rightarrow \mathrm{S}_{1}$ & $2.67[465 \mathrm{~nm}]$ & $\begin{array}{l}\text { HOMO } \rightarrow \text { LUMO } \\
\text { HOMO } \rightarrow \text { LUMO+1 }\end{array}$ & 0.1873 \\
\hline & $\mathrm{S}_{0} \rightarrow \mathrm{S}_{2}$ & $3.10[400 \mathrm{~nm}]$ & HOMO-1 $\rightarrow$ LUMO & 0.0061 \\
\hline
\end{tabular}

Data in the parenthesis show the experimental values.

with that of 0.09 deduced from integrating the molar extinction coefficient $\varepsilon$ of the first absorption band. In comparison to the experimental values, the results for both energy gap and oscillator strength are within $10 \%$ error, despite the negligence of solvation effects in the theoretical approach. For example, the Franck-Condon excited peak maximum of $\mathbf{2 a}$ in cyclohexane was measured to be $402 \mathrm{~nm}$, which is nearly identical to that of the calculated values, supporting the superiority of the TDB3LYP method in computing the excited state properties.
Another salient feature concerns the $\mathrm{S}_{0} \rightarrow \mathrm{S}_{2}$ transition, which mainly involves the HOMO-1 and LUMO frontier orbitals possessing a $\pi$ configuration in the phenyl ligand and a $\pi^{*}$ pattern in the pyridine (or quinoline) pyrrolide ligand, respectively (see Fig. 3). Thus, one would expect that the $S_{0} \rightarrow S_{2}$ transition incorporates an electron transfer process from the phenyl group to the pyridyl moiety for all three complexes (Table 2). Certainly, due to the fast internal conversion to the $\mathrm{S}_{1}$ state in the condensed phase, i.e., the Kasha's rule, the corresponding charge-transfer emission would be irresolvable. Nevertheless, these results together with data collected from our previous work ${ }^{[10]}$ suggested to us that if the HOMO located at the pyrrolide moiety could be further stabilized by introducing an electron-withdrawing group at the pyrrolide moiety, the HOMO-1 originally located on the phenyl ligand might eventually become the HOMO level. Accordingly, the lowest excited state possessing charge transfer character with a large dipolar change with respect to the ground state is expected. In fact, our preliminary results on the 5-(2-pyridyl) pyrazolate boron complexes (in which the addition of a nitrogen atom to the pyrrolide moiety, forming a pyrazole, further lowered the HOMO) have confirmed the existence of remarkable photoinduced charge transfer properties. ${ }^{[10]}$ These results (in particular the validity of the theoretical approach, in combination with rational design and synthesis) suggest that further studies on these systems are warranted.

\subsection{Electroluminescence}

Electroluminescent devices using complex $\mathbf{2 c}$ as the emitter were fabricated. Complex $2 \mathbf{c}$ was chosen due to the fact that it has the most red-shifted PL emission in solution. Taking advantage of the reasonably good energy overlap between the emission of tris(8-hydroxyquinoline)aluminum $\left(\mathrm{Alq}_{3}\right)$ and the $\mathrm{ab}$ sorption of $\mathbf{2 c}$, our devices consist of the conventional threelayer configuration ITO/NPB $(40 \mathrm{~nm}) / \mathrm{Alq}_{3}(30 \mathrm{~nm}): \mathbf{2 c}(0.5,2$, 5 , or $20 \%) / \mathrm{MgAg}$ (devices I-IV), where NPB as a hole transporting layer and $\mathrm{Alq}_{3}$ functions as an electron transporting layer as well as the host matrix for the orange emitting complex 2c. With a progressive increase of the dopant concentration from 0.5 to $20 \%$, the EL spectra became gradually red-shifted from yellow-orange at $\lambda_{\max }=560 \mathrm{~nm}$ to orange-red color at $\lambda_{\max }=574 \mathrm{~nm}$ (Fig. 4a). A near constant full width at half maximum (FWHM) of 80-82 nm was observed for all four devices I-IV, implying that the energy transfer between the host $\mathrm{Alq}_{3}$ (emission maximum around $520-530 \mathrm{~nm}$ ) and the dopant $\mathbf{2 c}$ should be sufficiently good under these experimental conditions. However, it was also noted that device IV with a dopant concentration of $20 \%$ exhibits a somewhat greater efficiency compared with the OLEDs using dopant concentrations of $2 \%$ and $5 \%$ (devices II or III) (Fig. 4b). Such behavior is in contrast to the typical EL devices, for which inferior performance was observed at higher dopant concentration because of the associated concentration quenching. ${ }^{[11]}$

We then proceeded to fabricate a non-doped OLED with a distinctive configuration of $\operatorname{ITO} / \mathrm{NPB}(40 \mathrm{~nm}) / \mathbf{2}(30 \mathrm{~nm}) /$ 

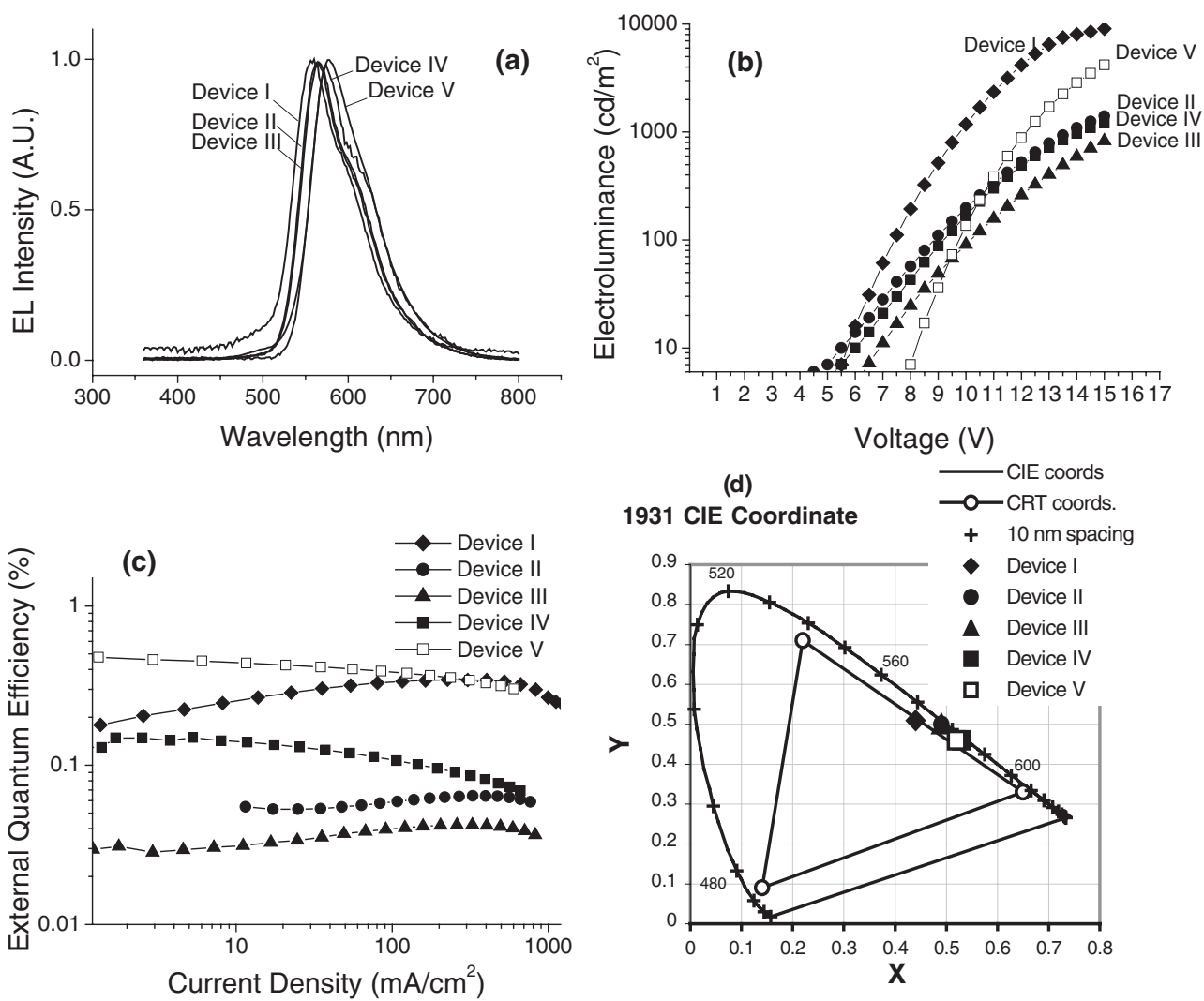

Figure 4. a) EL spectra of devices I-V. b) Voltage dependence of EL intensity of devices I-V. c) Current density dependence of external quantum efficiency of devices I-V. d) 1931 CIE color chromaticity diagram of devices I-V.

$\mathrm{BCP}(10 \mathrm{~nm}) / \mathrm{Alq}_{3}(30 \mathrm{~nm}) / \mathrm{MgAg}$ (device $\left.\mathrm{V}\right)$. A thin layer of hole blocking material $\mathrm{BCP}$ is applied to suppress the green emission from $\mathrm{Alq}_{3}$, which consequently increased the turn-on voltages from 5-6 $\mathrm{V}$ to $8 \mathrm{~V}$ with a maximum luminescence of $\sim 5000 \mathrm{~cd} \mathrm{~m}^{-2}$ achieved at the driving voltage of $15 \mathrm{~V}$. This OLED device is exceptional in two aspects. First of all, it exhibits relatively high intensity and efficiency of electroluminescence compared with those of the previously discussed devices I-IV (Fig. 4c) as well as the OLEDs fabricated using other boron-containing emitting materials. ${ }^{[1,4 c, 12]}$ It should be noted that only a limited number of non-doped orange or red fluorescent emitters have been documented in the literature. ${ }^{[13]}$ Secondly, the color chromaticity falls on the saturated redorange edge of the 1931 Commission Internationale de l'Eclairage color chromaticity diagram with coordinates $(0.55,0.45)$ (Fig. 4d), while the relatively small FWHM of the electroluminescent signals for $\mathbf{2 c}$ (Fig. 5) resembles that of the highly intensive and sharp emission signal observed for the fluorescence probes of BODIPY derivatives. ${ }^{[14]}$ In comparison to that in the solution phase, the sharpness of the electroluminescence in films may signify a rigidity of the phenyl ring in the solid state, reducing the rotational spectral broadening. A similar result was observed for the solid PL in 2c. However, no definite answer can be given to account for the reduced emission bandwidth observed in this class of boron-containing pyrrolide complexes.

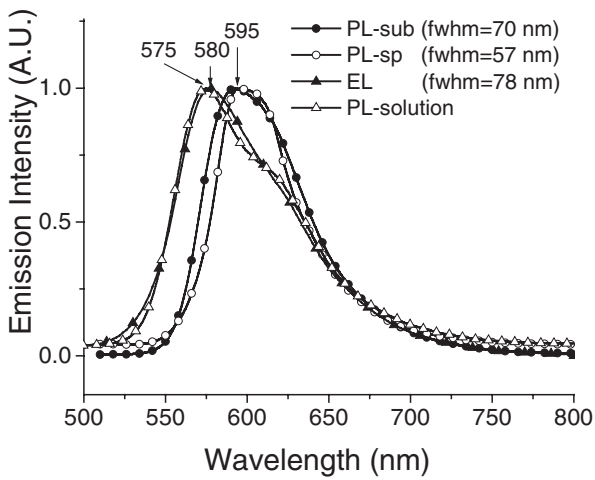

Figure 5. PL (PL-sub, PL-sp, and PL-solution) spectra of $2 c$ and $E L$ spectrum of device $\mathrm{V}$, where sub and sp denote solid film samples prepared by direct sublimation and spin-coating, respectively; $\mathrm{CH}_{2} \mathrm{Cl}_{2}$ is employed for the preparation of solution samples.

\section{Conclusion}

Boron complexes containing the substituted pyridyl pyrrolide type of chelate ligands have been synthesized. These boron complexes are thermally stable and show strong photoluminescence with emission spanning the longer wavelength region between blue-green $\left(\lambda_{\max }=490 \mathrm{~nm}\right)$ and red-orange $\left(\lambda_{\max }=572 \mathrm{~nm}\right.$ and $\left.595 \mathrm{~nm}\right)$ in the solid. A systematic variation 
of emission color was successfully achieved by changing the 2-pyridyl substituent with the more conjugated, 2-quinolinyl substituent. Further shifting the emission to the red region was made possible using the quinoxalinyl substituent, as it contains one additional electronegative nitrogen atom located on the LUMO section of the ligand chromophore. The TDDFT calculations precisely estimated the $S_{0} \rightarrow S_{1}$ energy gap, and showed in addition that the $S_{1}$ state can be well described using an allowed $\left(\pi\right.$-symmetry) $\rightarrow \pi^{*}$ ( $\pi$-symmetry) transition located at the substituted pyrrolide moieties of the corresponding boron complexes $\mathbf{2 a - 2 c}$. Non-doped OLED devices based on the redorange light-emitting $\left[(\right.$ xaro $\left.) \mathrm{BPh}_{2}\right](\mathbf{2 c})$ were demonstrated. The EL emission of $\mathbf{2 c}$ occurred at around $580 \mathrm{~nm}$ with brightness reaching a level as high as $5000 \mathrm{~cd} \mathrm{~m}^{-2}$ at $15 \mathrm{~V}$, showing its potential to serve as the emitting material for further OLED applications.

\section{Experimental}

\subsection{General Information and Materials}

All reactions were performed under nitrogen. Solvents were distilled from appropriate drying agents prior to use. Commercially available reagents were used without further purification unless otherwise stated. All reactions were monitored by TLC with Merck pre-coated glass plates $\left(0.20 \mathrm{~mm}\right.$ with fluorescent indicator $\left.\mathrm{UV}_{254}\right)$. Compounds were visualized with UV-light irradiation at $254 \mathrm{~nm}$ and $365 \mathrm{~nm}$. Flash column chromatography was carried out using silica gel from Merck (230-400 mesh). Mass spectra were obtained on a JEOL SX-102A instrument operating in electron impact (EI) mode or fast atom bombardment (FAB) mode. ${ }^{1} \mathrm{H}$ and ${ }^{13} \mathrm{C}$ NMR spectra were recorded on Varian Mercury-400 or INOVA-500 instruments; chemical shifts are quoted with respect to the internal standard tetramethylsilane for ${ }^{1} \mathrm{H}$ and ${ }^{13} \mathrm{C}$ NMR data. 2-Pyridine carboxaldehyde and 2-quinoline carboxaldehyde were purchased from Aldrich and used without further purification, while quinoxaline 2-carbaldehyde was prepared from the reaction of 2-methylquinoxaline with $\mathrm{SeO}_{2}$ according to a literature procedure [15].

\subsection{Synthesis of 5-Methyl-2-(2-pyridyl)pyrrole}

To a $100 \mathrm{~mL}$ flask equipped with a reflux condenser, methyl vinyl ketone (11 g, $0.15 \mathrm{~mol})$, 3-benzyl-5-(2-hydroxyethyl)-4-methylthiazolium chloride $(5 \mathrm{~g}, 0.02 \mathrm{~mol})$, and triethylamine $(10 \mathrm{~g}, 0.09 \mathrm{~mol})$ in $15 \mathrm{~mL}$ of anhydrous dioxane was refluxed for $30 \mathrm{~min}$. 2-Pyridinecarboxyaldehyde $(13 \mathrm{~g}, 0.12 \mathrm{~mol})$ in $25 \mathrm{~mL}$ of dry dioxane was subsequently added dropwise over a period of $60 \mathrm{~min}$, during which time the color gradually changed from yellow to green, and the mixture was continuously refluxed for another $12 \mathrm{~h}$. The mixture was then cooled to room temperature and the solvent removed under vacuum. Water was added and the mixture was extracted with $\mathrm{CH}_{2} \mathrm{Cl}_{2}(3 \times 50 \mathrm{~mL})$. After washing the extracts with brine, dehydration of organic extracts using $\mathrm{MgSO}_{4}$ and evaporation of $\mathrm{CH}_{2} \mathrm{Cl}_{2}$ solvent, the light yellow crude product of 1-(2-pyridyl)-pentane-1,4-dione was purified using silica gel flash column chromatography; $13 \mathrm{~g}$, yield: $60 \%$, lit. mp. $43-44{ }^{\circ} \mathrm{C}[16]$.

Spectral data: ${ }^{1} \mathrm{H}$ NMR $\left(400 \mathrm{MHz}, \mathrm{CDCl}_{3}\right): \delta 8.66\left(\mathrm{~d}, J_{\mathrm{HH}}=4.4 \mathrm{~Hz}\right.$, $1 \mathrm{H}), 8.00\left(\mathrm{~d}, J_{\mathrm{HH}}=8 \mathrm{~Hz}, 1 \mathrm{H}\right), 7.80\left(\mathrm{td}, J_{\mathrm{HH}}=6.8,2.0 \mathrm{~Hz}, 1 \mathrm{H}\right)$, $7.46-7.43(\mathrm{~m}, 1 \mathrm{H}), 3.48\left(\mathrm{t}, J_{\mathrm{HH}}=6 \mathrm{~Hz}, 2 \mathrm{H}\right), 2.86\left(\mathrm{t}, J_{\mathrm{HH}}=6 \mathrm{~Hz}, 2 \mathrm{H}\right)$, $2.22(\mathrm{~s}, 3 \mathrm{H}) .{ }^{13} \mathrm{C}$ NMR (100 MHz, $\left.\mathrm{CDCl}_{3}\right): \delta 207.1(\mathrm{C}), 200.2(\mathrm{C}), 153.0$ (C), $148.8(\mathrm{CH}), 136.7(\mathrm{CH}), 127(\mathrm{CH}), 121.6(\mathrm{CH}), 37\left(\mathrm{CH}_{3}\right), 31.7$ $\left(\mathrm{CH}_{3}\right), 29.8\left(\mathrm{CH}_{2}\right)$.

In a $100 \mathrm{~mL}$ round bottom flask equipped with a reflux condenser 1-(2-pyridyl)-pentane-1,4-dione $(2 \mathrm{~g}, 0.01 \mathrm{~mol})$ in $60 \mathrm{~mL}$ of anhydrous ethanol was heated with an excess of ammonium carbonate $(5 \mathrm{~g})$ and approximately $1 \mathrm{~mL}$ of $12 \mathrm{M} \mathrm{HCl}$ solution at $90^{\circ} \mathrm{C}$. After $12 \mathrm{~h}$, the solvent was evaporated under vacuum, the residue was extracted with $\mathrm{CH}_{2} \mathrm{Cl}_{2}(3 \times 50 \mathrm{~mL})$ to afford light yellow 5-methyl-2-(2-pyridyl) pyrrole (pyroH, 1a), which was further purified by flash column chromatography on silica gel; $1.7 \mathrm{~g}$, yield: $90 \%$, lit. mp $72-73^{\circ} \mathrm{C}$ [17].

Spectral data of 1a: ${ }^{1} \mathrm{H}$ NMR $\left(400 \mathrm{MHz}, \mathrm{CDCl}_{3}\right): \delta 9.86(\mathrm{br}, \mathrm{s}, 1 \mathrm{H}$, $\mathrm{NH}), 8.41\left(\mathrm{~d}, J_{\mathrm{HH}}=5.2 \mathrm{~Hz}, 1 \mathrm{H}\right), 7.56\left(\mathrm{dd}, J_{\mathrm{HH}}=7.6,1.6 \mathrm{~Hz}, 1 \mathrm{H}\right), 7.47$ $\left(\mathrm{dd}, J_{\mathrm{HH}}=8.0,1.0 \mathrm{~Hz}, 1 \mathrm{H}\right), 6.96\left(\mathrm{dd}, J_{\mathrm{HH}}=4.8,1.6 \mathrm{~Hz}, 1 \mathrm{H}\right), 6.59-6.58$ (m, 1H), 5.96-5.94 (m, 1H), $2.28(\mathrm{~s}, 3 \mathrm{H}) .{ }^{13} \mathrm{C} \mathrm{NMR}\left(100 \mathrm{MHz}, \mathrm{CDCl}_{3}\right)$ : $\delta 150.7(\mathrm{C}), 148.5(\mathrm{CH}), 136.3(\mathrm{CH}), 130.6(\mathrm{C}), 130(\mathrm{C}), 119.7(\mathrm{CH})$ $117.6(\mathrm{CH}), 108.2(\mathrm{CH}), 107.7(\mathrm{CH}), 12.9\left(\mathrm{CH}_{3}\right)$. Anal. Calcd for $\mathrm{C}_{10} \mathrm{H}_{10} \mathrm{~N}_{2}$ : C, 75.92; H, 6.37; N, 17.71. Found: C, 76.14; H, 6.34; N, 18.02.

\subsection{5-Methyl-2-(2-quinolinyl) and 5-Methyl-2-(2-quinoxalinyl)- pyrrole}

Other substituted pyrrole derivatives 5-methyl-2-(2-quinolinyl)pyrrole (noroH, 1b) and 5-methyl-2-(2-quinoxalinyl)pyrrole (xaroH, 1c) were prepared from 2-quinoline carboxaldehyde or quinoxaline 2-carbaldehyde with $40 \%$ and $42 \%$ yields, via a similar procedure to that described for the parent compound 5-methyl-2-(2-pyridyl)pyrrole (pyroH).

Spectral data of 1b: MS (EI), observed $\mathrm{m} / z$ [assignment]: 208 [ $\left.\mathrm{M}^{+}\right]$. ${ }^{1} \mathrm{H}$ NMR $\left(400 \mathrm{MHz}, \mathrm{CDCl}_{3}, 298 \mathrm{~K}\right): \delta 9.55(\mathrm{~b}, \quad 1 \mathrm{H}), 8.00(\mathrm{~d}$ $\left.J_{\mathrm{HH}}=8.8 \mathrm{~Hz}, 1 \mathrm{H}\right), 7.92\left(\mathrm{~d}, 1 \mathrm{H}, J_{\mathrm{HH}}=8.8 \mathrm{~Hz}, 1 \mathrm{H}\right), 7.70\left(\mathrm{~d}, J_{\mathrm{HH}}=8.0 \mathrm{~Hz}\right.$, $1 \mathrm{H}), 7.64-7.60(\mathrm{~m}, 2 \mathrm{H}), 7.39\left(\mathrm{t}, J_{\mathrm{HH}}=7.2 \mathrm{~Hz}, 1 \mathrm{H}\right), 6.73(\mathrm{~m}, 1 \mathrm{H}), 6.00$ $(\mathrm{m}, 1 \mathrm{H}), 2.32$ (s, 3H). Anal. Calcd for $\mathrm{C}_{14} \mathrm{H}_{12} \mathrm{~N}_{2}$ : C, 80.74; H, 5.81; $\mathrm{N}$ 13.45. Found: C, 80.71; H, 5.82; N, 13.47.

Spectral data of 1c: MS (EI), observed $m / z$ [assignment]: $207\left[\mathrm{M}^{+}\right]$. ${ }^{1} \mathrm{H}$ NMR $\left(400 \mathrm{MHz}, \mathrm{CDCl}_{3}, 298 \mathrm{~K}\right): \delta 9.64(\mathrm{~b}, 1 \mathrm{H}), 9.06(\mathrm{~s}, 1 \mathrm{H}), 7.98$ $\left(\mathrm{dd}, J_{\mathrm{HH}}=8.0,1.2 \mathrm{~Hz}, 1 \mathrm{H}\right), 7.87\left(\mathrm{dd}, J_{\mathrm{HH}}=8.0,0.4 \mathrm{~Hz}, 1 \mathrm{H}\right), 7.64(\mathrm{td}$, $\left.J_{\mathrm{HH}}=7.6,1.6 \mathrm{~Hz}, 1 \mathrm{H}\right), 7.56\left(\mathrm{td}, J_{\mathrm{HH}}=7.6,1.6 \mathrm{~Hz}, 1 \mathrm{H}\right), 6.89(\mathrm{~m}, 1 \mathrm{H})$ $6.04(\mathrm{~m}, 1 \mathrm{H}), 2.31(\mathrm{~s}, 3 \mathrm{H})$. Anal. Calcd. for $\mathrm{C}_{13} \mathrm{H}_{11} \mathrm{~N}_{3}: \mathrm{C}, 74.62 ; \mathrm{H}, 5.30$; N, 20.08. Found: C, 74.70; H, 5.29; N, 19.88

\subsection{Preparation of $\left[(\right.$ pyro $\left.) \mathrm{BPh}_{2}\right]$}

To a $50 \mathrm{~mL}$ reaction flask, was added $0.11 \mathrm{~g}$ of 5-methyl-2-(2-pyridyl) pyrrole (pyroH, 1a) $(0.7 \mathrm{mmol})$ and $20 \mathrm{~mL}$ of anhydrous tetrahydrofuran (THF). To this solution was added $3 \mathrm{~mL}$ of the $0.25 \mathrm{M}$ solution of $\mathrm{BPh}_{3}$ in THF $(0.75 \mathrm{mmol})$, and the mixture was stirred at room temperature for $4 \mathrm{~h}$. The solution was then concentrated to dryness and the residue was subjected to vacuum sublimation at $120^{\circ} \mathrm{C}$. Light yellow solid of [(pyro) $\mathrm{BPh}_{2}$ ] was obtained from recrystallization in a mixture of $\mathrm{CH}_{2} \mathrm{Cl}_{2}$ and hexane (2a, $0.14 \mathrm{~g}, 0.44 \mathrm{mmol}, 63 \%$ ).

Spectral data of 2a: MS (EI), observed $m / z$ [assignment]: $322\left[\mathrm{M}^{+}\right]$, $245\left[\mathrm{M}^{+}-\mathrm{Ph}\right] .{ }^{1} \mathrm{H}$ NMR $\left(400 \mathrm{MHz}, \mathrm{CDCl}_{3}, 298 \mathrm{~K}\right): \delta 8.04(\mathrm{~d}$ $\left.J_{\mathrm{HH}}=6.0 \mathrm{~Hz}, 1 \mathrm{H}\right), 7.72\left(\mathrm{t}, J_{\mathrm{HH}}=7.6 \mathrm{~Hz}, 1 \mathrm{H}\right), 7.46\left(\mathrm{~d}, J_{\mathrm{HH}}=8.0 \mathrm{~Hz}\right.$ $1 \mathrm{H}), 7.28-7.21(\mathrm{~m}, 10 \mathrm{H}), 6.88\left(\mathrm{t}, J_{\mathrm{HH}}=6.0 \mathrm{~Hz}, 1 \mathrm{H}\right), 6.73(\mathrm{~d}$ $\left.J_{\mathrm{HH}}=1.6 \mathrm{~Hz}, 1 \mathrm{H}\right), 6.14\left(\mathrm{~d}, J_{\mathrm{HH}}=1.6 \mathrm{~Hz}, 1 \mathrm{H}\right), 2.03(\mathrm{~s}, 3 \mathrm{H}) .{ }^{13} \mathrm{C} \mathrm{NMR}$ $\left(125 \mathrm{MHz}, \mathrm{CDCl}_{3}, 298 \mathrm{~K}\right): \delta 149.3(\mathrm{C}), 145.8(2 \mathrm{C}), 141.6(\mathrm{CH}), 140.3$ $(\mathrm{CH}), 137.9(\mathrm{C}), 133.6(4 \mathrm{CH}), 130.5(\mathrm{C}), 127.6(4 \mathrm{CH}), 126.7(2 \mathrm{CH})$, $117.7(\mathrm{CH}), 125.8(\mathrm{CH}), 113.5(\mathrm{CH}), 107.3(\mathrm{CH}), 13.9\left(\mathrm{CH}_{3}\right)$. Anal Calcd for $\mathrm{C}_{22} \mathrm{H}_{19} \mathrm{BN}_{2}: \mathrm{C}, 82.01 ; \mathrm{H}, 5.94 ; \mathrm{N}, 8.69$. Found: $\mathrm{C}, 82.43 ; \mathrm{H}$, $6.01 ; \mathrm{N}, 8.67$.

\subsection{Preparation of $\left[(\right.$ noro $\left.) \mathrm{BPh}_{2}\right]$}

A $50 \mathrm{~mL}$ reaction flask was charged with $0.5 \mathrm{~g}$ of 5-methyl-2-(2-quinolinyl) pyrrole (noroH, 1b) $(2.4 \mathrm{mmol})$ and $20 \mathrm{~mL}$ of anhydrous THF To this solution $9.7 \mathrm{~mL}$ of the $0.25 \mathrm{M}$ solution of $\mathrm{BPh}_{3}$ in THF $(2.4 \mathrm{mmol})$ was added and the mixture was stirred at room temperature for $6 \mathrm{~h}$. The solution was then concentrated to dryness and the res- 
idue was subjected to vacuum sublimation at $180^{\circ} \mathrm{C}$, giving $0.8 \mathrm{~g}$ of orange solid of [(noro) $\left.\mathrm{BPh}_{2}\right]$ (2b, $\left.2.15 \mathrm{mmol}, 89 \%\right)$.

Spectral data of $\mathbf{2 b}$ : MS (EI), observed $\mathrm{m} / z$ [assignment]: $372\left[\mathrm{M}^{+}\right]$, $295\left[\mathrm{M}^{+}-\mathrm{Ph}\right] .{ }^{1} \mathrm{H}$ NMR $\left(400 \mathrm{MHz}, \mathrm{CDCl}_{3}, 298 \mathrm{~K}\right): \delta 8.10(\mathrm{~d}$, $\left.J_{\mathrm{HH}}=8.8 \mathrm{~Hz}, 1 \mathrm{H}\right), 7.81\left(\mathrm{~d}, J_{\mathrm{HH}}=8.8 \mathrm{~Hz}, 1 \mathrm{H}\right), 7.66\left(\mathrm{~d}, J_{\mathrm{HH}}=8.0 \mathrm{~Hz}\right.$, $1 \mathrm{H}), 7.61\left(\mathrm{~d}, J_{\mathrm{HH}}=8.8 \mathrm{~Hz}, 1 \mathrm{H}\right), 7.39-7.34(\mathrm{~m}, 2 \mathrm{H}), 7.28-7.15(\mathrm{~m}$, $10 \mathrm{H}), 6.87\left(\mathrm{~d}, J_{\mathrm{HH}}=3.6 \mathrm{~Hz}, 1 \mathrm{H}\right), 6.15\left(\mathrm{~d}, J_{\mathrm{HH}}=3.6 \mathrm{~Hz}, 1 \mathrm{H}\right), 1.96(\mathrm{~s}$, $3 \mathrm{H}) .{ }^{13} \mathrm{C}$ NMR $\left(125 \mathrm{MHz}, \mathrm{CDCl}_{3}, 298 \mathrm{~K}\right): \delta 149.7$ (C), 144.5 (2C), $140.9(\mathrm{CH}), 140.7(\mathrm{C}), 140.1(\mathrm{C}), 134.2(4 \mathrm{CH}), 131.9(\mathrm{C}), 131.3(\mathrm{CH})$, $128.7(\mathrm{CH}), 127.4(4 \mathrm{CH}), 126.4(2 \mathrm{CH}), 125.7(\mathrm{C}), 124.7(\mathrm{CH}), 121.8$ $(\mathrm{CH}), 115.0(\mathrm{CH}), 114.7(\mathrm{CH}), 109.3(\mathrm{CH}), 14.0\left(\mathrm{CH}_{3}\right)$. Anal. Calcd for $\mathrm{C}_{26} \mathrm{H}_{21} \mathrm{BN}_{2}$ : $\mathrm{C}, 83.89 ; \mathrm{H}, 5.69 ; \mathrm{N}, 7.53$. Found: $\mathrm{C}, 83.98 ; \mathrm{H}, 5.84 ; \mathrm{N}$, 7.40 .

\subsection{Preparation of $\left[(\mathrm{xaro}) \mathrm{BPh}_{2}\right]$}

A $50 \mathrm{~mL}$ reaction flask was charged with $0.2 \mathrm{~g}$ of 5-methyl-2-(2-quinoxalinyl) pyrrole $(\mathrm{xaroH}, \mathbf{1 c})(0.96 \mathrm{mmol})$ and $20 \mathrm{~mL}$ of anhydrous THF. To this solution was added $5.7 \mathrm{~mL}$ of the $0.25 \mathrm{M}$ solution of $\mathrm{BPh}_{3}$ in THF (1.44 mmol), and the mixture was heated to reflux for $12 \mathrm{~h}$. The solution was then concentrated to dryness. Red crystals of [(xaro) $\mathrm{BPh}_{2}$ ] were obtained from a mixed solution $\mathrm{CH}_{2} \mathrm{Cl}_{2}$ and methanol (2c, $0.8 \mathrm{~g}, 2.15 \mathrm{mmol}, 75 \%$ ).

Spectral data of 2c: MS (EI), observed $m / z$ [assignment]: $373\left[\mathrm{M}^{+}\right]$, $296\left[\mathrm{M}^{+}-\mathrm{Ph}\right.$ ]. ${ }^{1} \mathrm{H}$ NMR $\left(400 \mathrm{MHz}, \mathrm{CDCl}_{3}, 298 \mathrm{~K}\right): \delta 9.14(\mathrm{~s}, 1 \mathrm{H})$, 7.95-7.98 (m, 1H), 7.70-7.72 (m, 1H), 7.40-7.42 (m, 2H), 7.31-7.33 (m, $4 \mathrm{H}), \quad 7.20-7.25(\mathrm{~m}, 6 \mathrm{H}), 7.02\left(\mathrm{~d}, J_{\mathrm{HH}}=3.6 \mathrm{~Hz}, 1 \mathrm{H}\right), 6.25(\mathrm{~d}$, $\left.J_{\mathrm{HH}}=3.6 \mathrm{~Hz}, 1 \mathrm{H}\right), 1.99(\mathrm{~s}, 3 \mathrm{H}) \cdot{ }^{13} \mathrm{C}$ NMR $\left(125 \mathrm{MHz}, \mathrm{CDCl}_{3}, 298 \mathrm{~K}\right): \delta$ 143.6 (C), 143.0 (2C), $142.3(\mathrm{CH}), 141.4$ (C), 140.0 (C), $134.0(4 \mathrm{CH})$, $133.9(\mathrm{C}), 131.8(\mathrm{CH}), 130.4(\mathrm{CH}), 130.1(\mathrm{C}), 127.6(4 \mathrm{CH}), 126.9$ $(2 \mathrm{CH}), 126.9(\mathrm{CH}), 121.2(\mathrm{CH}), 116.8(\mathrm{CH}), 112.0(\mathrm{CH}), 14.2\left(\mathrm{CH}_{3}\right)$ Anal. Calcd. for $\mathrm{C}_{25} \mathrm{H}_{20} \mathrm{~N}_{3}$ : C, 80.45; H, 5.40; N, 11.26. Found: C, 80.07; $\mathrm{H}, 5.30 ; \mathrm{N}, 11.09$.

\subsection{X-Ray Crystallography Analysis}

Single-crystal X-ray diffraction data were measured on a Bruker SMART Apex charge-coupled device (CCD) diffractometer using $\lambda(\operatorname{MoK} \alpha)$ radiation $(\lambda=0.71073 \AA)$. The data collection was executed using the SMART program. Cell refinement and data reduction were made by the SAINT program. The structure was determined using SHELXTL/PC program and refined using full-matrix least squares. All non-hydrogen atoms were refined anisotropically, whereas hydrogen atoms were placed at the calculated positions and included in the final stage of refinements with fixed parameters. Crystallographic refinement parameters of complex $\mathbf{2 c}$ are summarized in Table 3, while the selective bond distances and angles are listed in Table 4. The crystallographic data of this complex (excluding structure factors) has been deposited to the Cambridge Crystallographic Data Centre with the allocated deposition number CCDC-244482. This data can be obtained free of charge on application to CCDC, 12 Union Road, Cambridge CB21EZ, UK (fax: (+44) 1223-336-033; e-mail: deposit@ccdc.cam. ac.uk).

\subsection{Photophysical Measurement}

Steady-state absorption and emission spectra were recorded by a Hitachi (U-3310) spectrophotometer and an Edinburgh (FS920) fluorimeter, respectively. Both wavelength-dependent excitation and emission response of the fluorimeter have been calibrated. DCM (4-(dicyanomethylene)-2-methyl-6-( $p$-dimethylaminostyryl)-4H-pyran, $\lambda_{\mathrm{em}}=615 \mathrm{~nm}$, Exciton $)$ in methanol and Coumarine $480\left(\lambda_{\mathrm{em}}=471 \mathrm{~nm}\right.$, Exciton) in ethanol, with $\Phi$ of $\sim 0.43$ [18] and 0.95 [19], respectively, served as the standard for measuring the emission quantum yield. $\mathrm{Na}-$
Table 3. X-ray structural data of complex 2c.

\begin{tabular}{|c|c|}
\hline $\mathrm{C}_{25} \mathrm{H}_{20} \mathrm{BN}_{3}$ & mol. wt. $=373.25$ \\
\hline monoclinic, $\mathrm{P} 2_{1} / \mathrm{n}$ & Temp. $=295(2)[\mathrm{K}]$ \\
\hline$a=10.7130(5)[\AA \AA]$ & $b=16.1890(9)[\AA]$ \\
\hline$c=11.5701(6)[\AA]$ & $\beta=99.8872(12)^{\circ}$ \\
\hline Vol. $=1976.8(2)\left[\AA^{3}\right]$ & $Z=4$ \\
\hline$D_{c}=1.254\left[\mathrm{gcm}^{-3}\right]$ & $F(000)=784$ \\
\hline$\mu(\mathrm{MoK} \alpha)\left[\mathrm{mm}^{-1}\right]$ & 0.074 \\
\hline crystal size $[\mathrm{mm}]$ & $0.40 \times 0.30 \times 0.05$ \\
\hline$h, k, I$ ranges & $-1312,-2121,-1515$ \\
\hline transmission: $\max ,[\mathrm{min}]$ & $0.9963,0.9710$ \\
\hline data / restraints / parameters & $4529 / 0 / 264$ \\
\hline GOF on $\mathrm{F}^{2}$ & 1.042 \\
\hline$R_{1}$, w $R_{2}$ with $I>2 \sigma(I)$ & $0.0623,0.1305$ \\
\hline D-map, $\operatorname{maxmin}^{-1},\left[\mathrm{e} \AA^{-3}\right]$ & $0.209 /-0.147$ \\
\hline
\end{tabular}

Table 4. Selected bond distances $(\AA)$ and angles $\left({ }^{\circ}\right)$ for complex $\mathbf{2 c}$.

\begin{tabular}{llll}
\hline $\mathrm{B}(1)-\mathrm{N}(1)$ & $1.568(3)$ & $\mathrm{B}(1)-\mathrm{N}(2)$ & $1.632(2)$ \\
$\mathrm{B}(1)-\mathrm{C}(14)$ & $1.606(3)$ & $\mathrm{B}(1)-\mathrm{C}(20)$ & $1.610(3)$ \\
$\mathrm{N}(1)-\mathrm{C}(2)$ & $1.348(2)$ & $\mathrm{C}(2)-\mathrm{C}(3)$ & $1.389(3)$ \\
$\mathrm{C}(3)-\mathrm{C}(4)$ & $1.377(3)$ & $\mathrm{C}(4)-\mathrm{C}(5)$ & $1.389(3)$ \\
$\mathrm{C}(5)-\mathrm{C}(6)$ & $1.413(3)$ & $\mathrm{C}(6)-\mathrm{C}(7)$ & $1.420(3)$ \\
$\mathrm{N}(2)-\mathrm{C}(6)$ & $1.345(2)$ & $\mathrm{N}(3)-\mathrm{C}(7)$ & $1.295(3)$ \\
$\mathrm{N}(3)-\mathrm{C}(8)$ & $1.379(3)$ & $\mathrm{N}(2)-\mathrm{C}(13)$ & $1.380(2)$ \\
$\mathrm{C}(8)-\mathrm{C}(13)$ & $1.409(3)$ & & \\
$\mathrm{N}(1)-\mathrm{B}(1)-\mathrm{N}(2)$ & $94.5(1)$ & $\mathrm{CC}(14)-\mathrm{B}(1)-\mathrm{C}(20)$ & $119.3(2)$ \\
\hline
\end{tabular}

nosecond lifetime studies were performed by an Edinburgh FL 900 photon-counting system with a hydrogen-filled/or a nitrogen lamp as the excitation source. Data were analyzed using the nonlinear least squares procedure in combination with an iterative convolution method. The emission decays were analyzed by the sum of exponential functions, which allows partial removal of the instrument time broadening and consequently renders a temporal resolution of $\sim 200 \mathrm{ps}$.

\subsection{Theoretical Calculations}

All calculations were performed using density functional theory (DFT) as implemented in the Gaussian 98 program [20]. The geometry optimization of the boron complexes was calculated at the electronic ground state using the hybrid density functional theories (DFT) B3LYP $[9,21]$ with $6-31 \mathrm{G}\left(\mathrm{d}^{\prime}, \mathrm{p}^{\prime}\right)$ basis set [22]. The vertical excitation energies and oscillator strengths of the excited states for the complexes were then computed by the time-dependent DFT (TDDFT) method $[22 \mathrm{~b}, \mathrm{c}]$ using the same hybrid functional and basis set at the respective optimized ground-state geometries.

\subsection{Device Fabrication}

The OLED devices using complex $\mathbf{2 c}$ as the dopant-emitter (devices I-IV) or non-doped, host-emitter (device V) were fabricated on indium tin oxide (ITO) coated glass substrate. All organic substances were first purified by train sublimation and then deposited on the glass substrate in sequence by conventional direct deposition [23]. NPB (1,4-bis(1naphthylphenylamino)biphenyl) was utilized as hole-transporting layer, while BCP (bathocuproine) was used as the hole-blocking layer in device $\mathrm{V}$. $\mathrm{Alq}_{3}$ was used as electron-transporting material (devices I-IV) or as the host matrix for $\mathbf{2 c}$ as well as the electron-transporting material (device $\mathrm{V}$ ).

Received: June 8, 2004 Final version: July 6, 2004 
[1] a) S. Wang, Coord. Chem. Rev. 2001, 215, 79. b) S. Anderson, M. S Weaver, A. J. Hudson, Synth. Met. 2000, 111-112, 459. c) Y. Li, Y. Liu, W. Bu, J. Guo, Y. Wang, Chem. Commun. 2000, 1551.

[2] a) G. Beer, J. Daub, K. Rurack, Chem. Commun. 2001, 1138. b) K. Rurack, M. Kollmannsberger, U. Resch-Genger, J. Daub, J. Am. Chem. Soc. 2000, 122, 968. c) K. Rurack, M. Kollmannsberger, J. Daub, Angew. Chem. Int. Ed. 2001, 40, 385.

[3] a) J. Chen, A. Burghart, A. Derecskei-Kovacs, K. Burgess, J. Org. Chem. 2000, 65, 2900. b) A. Burghart, L. H. Thoresen, J. K. Burgess, F. Bergstrom, L. B. Johansson, Chem. Commun. 2000, 2203.

[4] a) K. Albrecht, V. Kaiser, R. Boese, J. Adams, D. E. Kaufmann, J. Chem. Soc. Perkin Trans. 2 2000, 2, 2153. b) W.-L. Jia, D. Song, S. Wang, J. Org. Chem. 2003, 68, 701. c) Q. Wu, M. Esteghamatian, N.-X. Hu, Z. Popovic, G. Enright, Y. Tao, M. D'Iorio, S. Wang, Chem. Mater. 2000, 12, 79. d) S.-F. Liu, Q. Wu, H. L. Schmider, H. Aziz, N.X. Hu, Z. Popovic, S. Wang, J. Am. Chem. Soc. 2000, 122, 3671.

[5] a) C. H. Chen, J. Shi, Coord. Chem. Rev. 1998, 171, 161. b) L. S. Sapochak, A. Padmaperuma, N. Washton, F. Endrino, G. T. Schmett, J. Marshall, D. Fogarty, P. E. Burrows, S. R. Forrest, J. Am. Chem. Soc. 2001, 123, 6300 .

[6] R. A. Jones, M. Karatza, T. N. Voro, P. U. Civcir, A. Franck, O. Ozturk, J. P. Seaman, A. P. Whitmore, D. J. Williamson, Tetrahedron 1996, 52, 8707

[7] a) F. Wu, C. M. Chamchoumis, R. P. Thummel, Inorg. Chem. 2000, 39, 584. b) J. J. Klappa, S. A. Geers, S. J. Schmidtke, L. A. MacManusSpencer, K. McNeill, J. Chem. Soc. Dalton Trans. 2004, 883.

[8] a) U. Mitschke, P. Bauerle, J. Mater. Chem. 2000, 10, 1471. b) A. J. Campbell, D. D. C. Bradley, T. Virgili, D. G. Lidzey, H. Antoniadis, Appl. Phys. Lett. 2001, 79, 3872. c) Y.-Y. Chien, K.-T. Wong, P.-T. Chou, Y.-M. Cheng, Chem. Commun. 2002, 2874. d) S. Destri, M. Pasini, C. Botta, W. Porzio, F. Bertini, L. Marchio, J. Mater. Chem. 2002 $12,924$.

[9] A. D. Becke, J. Chem. Phys. 1993, 98, 5648.

[10] C.-C. Cheng, W.-S. Yu, P.-T. Chou, S.-M. Peng, G.-H. Lee, P.-C. Wu, Y.-H. Song, Y. Chi, Chem. Commun. 2003, 2628.

[11] C.-T. Chen, Chem. Mater. 2004, 16, 4386.

[12] a) X. T. Tao, H. Suzuki, T. Wada, H. Sassabe, S. Miyata, Appl. Phys. Lett. 1999, 75, 1655. b) Q. Wu, M. Esteghamatian, N.-X. Hu, Z. Popovic, G. Enright, S. R. Breeze, S. Wang, Angew. Chem. Int. Ed. 1999, 38, 985. c) S.-F. Liu, C. Seward, H. Aziz, N.-X. Hu, Z. Popovic, S. Wang, Organometallics 2000, 19, 5709. d) H. J. Lim, S. M. Kim, S.-J. Lee, S. Jung, Y. K. Kim, Y. Ha, Opt. Mater. 2002, 21, 211. e) F. S. Liang, Y. X. Cheng, G. P. Su, D. G. Ma, L. X. Wang, X. B. Jing, F. S. Wang, Synth. Met. 2003, 137, 1109. f) Q. Liu, M. S. Mudadu, H. Schmider, R. Thummel, Y. Tao, S. Wang, Organometallics 2002, 21, 4743. g) W.-L. Jia, D.-R. Vai, T. McCirmick, Q.-D. Liu, M. Motala, R.-Y. Wang, C. Seward, Y. Tao, S. Wang, Chem. Eur. J. 2004, 10, 944
[13] a) D. U. Kim, S. H. Paik, S.-H. Kim, T. Tsutsui, Synth. Met. 2001, 123 43. b) L. S. Hung, C. H. Chen, Mater. Sci. Eng. 2002, R39, 143 c) K. R. J. Thomas, J. T. Lin, Y.-T. Tao, C.-H. Chuen, Adv. Mater 2002, 14, 822. d) W.-C. Wu, H.-C. Yeh, L.-H. Chan, C.-T. Chen, $A d v$. Mater. 2002, 14, 1072. e) H.-C. Yeh, S.-J. Yeh, C.-T. Chen, Chem. Commun. 2003, 2632. f) T.-H. Huang, J. T. Lin, Y. T. Tao, C.-H. Chuen, Chem. Mater. 2003, 15, 4584. g) K. R. J. Thomas, J. T. Lin, M. Velusamy, Y.-T. Tao, C.-H. Chuen, Adv. Funct. Mater. 2004, 14, 83.

[14] a) A. Burghart, H. Kim, M. B. Welch, L. H. Thoresen, J. Reibenspies, K. Burgess, J. Org. Chem. 1999, 64, 7813. b) H. Kim, A. Burghart, M. B. Welch, J. Reibenspies, K. Burgess, Chem. Commun. 1999, 1889. c) K. Yamada, T. Toyota, K. Takakura, M. Ishimaru, T. Sugawara, New J. Chem. 2001, 25, 667. d) M. Wada, S. Ito, H. Uno, T. Murashima, N. Ono, T. Uran, Y. Urano, Tetrahedron Lett. 2001, 42, 6711. e) K. Rurack, M. Kollmannsberger, J. Daub, Angew. Chem. Int. Ed. 2001, 40, 385. f) R. Y. Lai, A. J. Bard, J. Phys. Chem. B 2003, 107, 5036.

[15] S. E. Page, A. Flood, K. C. Gordon, J. Chem. Soc. Dalton Trans. 2002, 1180.

[16] R. A. Jones, M. Karatza, T. N. Voro, P. U. Civcir, A. Franck, O. Ozturk, J. P. Seaman, A. P. Whitmore, D. J. Williamson, Tetrahedron 1996, 52, 8707 .

[17] T. Severin, R. Adam, Chem. Ber. 1975, 108, 88.

[18] J. M. Drake, M. L. Lesiecki, D. M. Camaioni, Chem. Phys. Lett. 1985, $113,530$.

[19] G. Jones, W. R. Jackson, C. Y. Choi, W. R. Bergmark, J. Phys. Chem. 1985, 89, 294.

[20] M. J. Frisch, G. W. Trucks, H. B. Schlegel, G. E. Scuseria, M. A. Robb, J. R. Cheeseman, V. G. Zakrzewski, J. A. Montgomery, R. E. Stratmann, J. C. Burant, S. Dapprich, J. M. Millam, A. D. Daniels, K. N. Kudin, M. C. Strain, O. Farkas, J. Tomasi, V. Barone, M. Cossi, R. Cammi, B. Mennucci, C. Pomelli, C. Adamo, S. Clifford, J. Ochterski, G. A. Petersson, P. Y. Ayala, Q. Cui, K. Morokuma, D. K. Malick, A. D. Rabuck, K. Raghavachari, J. B. Foresman, J. Cioslowski, J. V. Ortiz, B. B. Stefanov, G. Liu, A. Liashenko, P. Piskorz, I. R. Gomperts, R. L. Martin, D. J. Fox, T. Keith, M. A. Al-Laham, C. Y. Peng, A. Nanayakkara, C. Gonzalez, M. Challacombe, P. M. W. Gill, B. G. Johnson, W. Chen, M. W. Wong, J. L. Andres, M. Head-Gordon, E. S. Replogle, J. A. Pople, Gaussian 98, revision A.7, Gaussian, Inc., Pittsburgh, PA, USA 1998.

[21] R. G. Parr, W. Yang, Density-Functional Theory of Atoms and Molecules, Oxford University Press, New York 1989

[22] a) G. A. Petersson, M. A. Al-Laham, J. Chem. Phys. 1991, 94, 6081. b) R. Bauernschmitt, R. Ahlrichs, Chem. Phys. Lett. 1996, 256, 454. c) M. E. Casida, C. Jamorski, K. C. Casida, D. R. Salahub, J. Chem. Phys. 1998, 108, 4439.

[23] L.-H. Chan, R.-H. Lee, C.-F. Hsieh, H.-C. Yeh, C.-T. Chen, J. Am Chem. Soc. 2002, 124, 6469. 